\title{
Influence of Surah Ar-Rahman Murottal on Anxiety Level and Labor Duration of Active Phase Stage I in Rskdia Siti Fatimah Makassar
}

\author{
Irmawati $^{1}$, Veni Hadju ${ }^{2}$, Saidah Syamsuddin ${ }^{3}$, Asri $^{4^{*}}$, Safruddin $^{5}$ \\ ${ }^{1}$ School of Health Science Panrita Husada Bulukumba, Indonesia \\ ${ }^{2}$ Faculty of Public Health Section Hasanuddin University, Indonesia \\ ${ }^{3}$ Psychology Section, Faculty of Medicine, Hasanuddin University, Indonesia \\ ${ }^{4}$ School of Health Science, Panrita Husada Bulukumba, Indonesia \\ *Corresponding Author \\ Mr. Asri Asri
}

\section{Article History}

Received: 03.03.2020

Accepted: 10.03 .2020

Published: 23.03.2020

\begin{abstract}
Background: One non-pharmacological therapy that can be used to recover is to use distraction techniques with the verses of the Qur'an that can privilege delta waves that cause the listener to be in a calm, peaceful state. Purpose: This study discusses the influence of murottal surah Ar-Rahman on the level of discussion and time of labor in the first phase of active phase. The research design method used was an experimental study with a pretestposttest research design with a control group design. The research sample was first phase active maternity mothers in primiparous in Siti Fatimah Hospital Makassar. Research samples of 40 samples (20 samples for murottal and 20 samples for control) were chosen and adjusted intentionally. Data were analyzed by chi-square test. Results: There was a level of participation in murottal group respondents before and after the intervention was given, namely $\mathrm{p}=0,000(\mathrm{p}<0.05)$, whereas in control group respondents who were not given murottal, there was no change in the value of $p=0.157(\alpha>0$, 05). Likewise, the difference in cortisol levels between the murottal group and the control group and the time of delivery after murottal showed an influence on both groups with a value of $p=0.001(\mathrm{p}<0.05)$. And for the relationship of cortisol level with the level of participation indicated by the coefficient value $r=0.690$. Conclusion: There are certain levels, cortisol levels and time of labor in the first phase of the active phase before and after murottal. It is thought that this is the best that can be used in providing effective non-pharmacological relaxation therapy and is also inexpensive in the delivery of labor that can increase the rate of benefit and time of delivery.
\end{abstract}

Keywords: Surah Ar-Rahman, taking, cortisol, time of delivery.

\section{INTRODUCTION}

Normal labor and delivery is a process of expulsion of the fetus that occurs in full-term pregnancies, spontaneous births with the presentation of the back of the head that lasts within 18 hours, without complications both in the mother and in the fetus with signs of pain by the presence of his coming stronger, often and regularly, more bloody mucus comes out (show) because of small tears in the cervix, sometimes the membranes rupture by themselves, on examination in the cervix horizontally and opening has been present [1].

First stage labor is the stage of labor in which uterine contractions occur which causes softening and stretching of the cervix. This phase will last for $\pm 13-14$ hours in primipara and \pm 6-7 hours in multipara. This phase ends if the cervix has fully opened $10 \mathrm{~cm}$ [12]. AKI (Angka kematian Ibu) di Indonesia tahun 2010 berdasarkan hasil survey demografi kesehatan Indonesia (SDKI) mencapai 228 per 100.000 kelahiran hidup dan angka kematian bayi tahun 2010 sebesar 34/1000 kelahiran hidup. Jumlah Ibu yang meninggal karena kehamilan dan persalinan tahun 2013 adalah sebanyak 5019 orang [2]. Penyebab utama kematian ibu di Indonesia adalah hipertensi sebesar 38\%, sedangkan perdarahan menempati urutan ke dua yaitu $30 \%[2]$.

Copyright @ 2020: This is an open-access article distributed under the terms of the Creative Commons Attribution license which permits unrestricted use, distribution, and reproduction in any medium for non commercial use (NonCommercial, or CC-BY-NC) provided the original author and source are credited. 
Progress of labor in the first phase of the active phase is the most tiring, severe, and most mothers begin to feel pain or pain, in this phase most mothers feel severe pain because uterine activity begins to be more active. In this phase the contractions get longer, stronger and more often, which can cause anxiety. Anxiety in the first stage of birth can affect the increase in adrenaline secretion. One effect of adrenaline is constriction of blood vessels so that oxygen supply to the fetus decreases. Decreased blood flow also causes a weakening of uterine contractions and results in prolonged labor and can cause prolonged labor [3].

One non-pharmacological therapy that can be used to reduce anxiety is to use distraction techniques with the verses of the Qur'an that can stimulate delta waves that cause the listener to be calm, peaceful. The religious relaxation that Benson developed combining relaxation with the factor of belief can create inner strength that helps a person in a relaxed state. By analogizing that the reading of the Qur'an also has a slow, regular and gentle tempo and the belief factor is expected to hear the reading of the Qur'an can cause relaxation [4].

The results of research conducted by Rohmi Handayani [2] about the effect of murottal Al-Qur'an therapy for the reduction of labor pain and anxiety in first-time mothers in active phase the average anxiety before murottal therapy was 26.67 , after murottal therapy was 20,52 . This shows that there are differences in the average decrease in anxiety levels before and after murottal therapy. Likewise, the research results of Sukma Amperiana [11, 5] found that there is an influence of music on the progress of labor in the first phase of active phase that is equal to $44.4 \%$. This study aims to determine the effect of the surah Ar-Rahman murottal on the level of anxiety and time of the first phase of active labor in Siti Fatimah Makassar Hospital.

\section{METHODS}

This research was conducted on April 3 - May 3, 2019. Location in RSKDIA Siti Fatimah Makassar. This research uses Quasi experimental research with pretest-posttest with control group design. Namely knowing the effect of the surah Ar-Rahman murottal on the level of anxiety and time of the first phase of active labor in Siti Fatimah Makassar Hospital.

The population in this study was all mothers giving birth to active phase Primigravida I in the Mother and Child Regional Health Hospital (RSKDIA) Siti Fatimah Makassar as many as 50 people. The sample in this study was that most mothers gave birth to primigravidas at the time the study was conducted. Sampling in this study is to use a purposive sampling technique where the sample to be used is determined by the inclusion and exclusion criteria. Data collection was obtained directly from the results of measurements of respondent cortisol levels and also carried out by direct observation and systematic recording of objects to be studied. Observations were carried out by researchers by means of observations and records regarding: the level of anxiety and time of delivery using the laboratory of the teaching hospital of Hasanuddin University. Analisis berupa analisis univariat dan bivariat merupakan analisa hasil dari variabel-variabel bebas yang diduga mempunyai hubungan dengan variabel terkait. Analysis of the data used is the ChiSquare test. So that it can be known whether or not there is influence statistically, using the SPSS for Windows computer program. Through the Chi-Square test then a conclusion is drawn, if the value of $\mathrm{p}<0.05$ then Ha is accepted, which indicates the influence of the dependent variable with the independent variable. Meanwhile, if the value of $p>0.05$ then Ho is rejected, which shows that there is no influence between the dependent variable and the independent variable

\section{RESULTS}

Table-1: Anxiety level before and after Murottal between the murottal group and the control group

\begin{tabular}{|c|c|c|c|c|c|c|c|c|c|c|}
\hline Level & \multicolumn{4}{|c|}{ Murottal $(n=20)$} & \multirow[t]{3}{*}{$p$} & \multicolumn{4}{|c|}{ control $(n=20)$} & \multirow[t]{3}{*}{$p$} \\
\hline Anxiety & \multicolumn{2}{|c|}{ Pre } & \multicolumn{2}{|c|}{ Post } & & \multicolumn{2}{|c|}{ Pre } & \multicolumn{2}{|c|}{ Post } & \\
\hline & $\mathrm{n}$ & $\%$ & $\mathrm{n}$ & $\%$ & & $\mathrm{n}$ & $\%$ & $\mathrm{n}$ & $\%$ & \\
\hline Mild & 0 & 0 & 14 & 70 & 0,000 & 0 & 0 & 0 & 0 & 0,157 \\
\hline Moderate & 14 & 70 & 5 & 25 & & 6 & 30 & 4 & 20 & \\
\hline Severe & 6 & 30 & 1 & 5 & & 14 & 70 & 16 & 80 & \\
\hline
\end{tabular}

In the murottal group, between before being played with and after being heard there was an increase from a mild anxiety level of $0 \%$ to 14 people $(70 \%)$, anxiety with a moderate level before murottal as many as 14 people (70\%), after murottal to 5 people (25\%), and severe anxiety before murottal as many as 6 people (30\%), after murottal became 1 person (5\%). In the control group, between before and after decreased anxiety levels. Namely moderate anxiety from 6 people $(30 \%)$ to 4 people (20\%). And severe anxiety from 14 people $(70 \%)$ to 16 people $(80 \%)$. 
Table-2: Differences in the level of anxiety before and after the murottal group and the control group at Siti Fatimah Hospital Makassar

\begin{tabular}{|l|c|c|c|c|c|c|}
\hline \multirow{3}{*}{ Group } & \multirow{2}{*}{$\mathbf{n}$} & \multicolumn{2}{|c|}{ Anxiety } & \multirow{2}{*}{$\boldsymbol{P}$ pre-post } & \multirow{2}{*}{$\boldsymbol{P}$} \\
\cline { 3 - 4 } & & Pre & Post & & \\
\cline { 3 - 4 } \cline { 3 - 5 } & & mean \pm SD & mean \pm SD & & Mean $\pm S D$ & 0,000 \\
\hline Murottal & 20 & $3,30 \pm 0,47$ & $2,35 \pm 0,58$ & 0,000 & $--0.42 \pm 0,59$ & \\
\hline Control & 20 & $3,70 \pm 0,47$ & $3,80 \pm 0,41$ & 0,157 & $1,50 \pm 0,50$ & \\
\hline
\end{tabular}

The average level of anxiety after the murottal group is smaller, which is 2.35 with a standard deviation of 0.58 . The average difference in the level of anxiety before and after the murottal group is -0.42 with a standard deviation of 0.59. Statistical test results using the Wilcoxon test showed a significant difference in the level of anxiety before and after treatment in the murottal group $\mathrm{p}=0,000(\mathrm{p}<0.05)$. In the control group that was not given murottal, the average level of anxiety before and after was 1.50 with a standard deviation of 0.50 . Statistical test results using Wilcoxon test showed no difference between anxiety levels before and after in the control group with a value of $p=0.157(p>0.05)$. So that it can be concluded that there are significant differences between the murottal group and the control group before and after murottal anxiety level with a value of $p=0,000(p<0.05)$.

Differences in cortisol levels in the murottal and control groups, seen the average cortisol levels in the murottal group is $307 \mathrm{nmol} / \mathrm{L}$ and the control group is $1642 \mathrm{nmol} / \mathrm{L}$. Statistical test results using the Mann Whitney U test obtained $\mathrm{p}$ value $=0,000(\mathrm{p}<0.05)$.

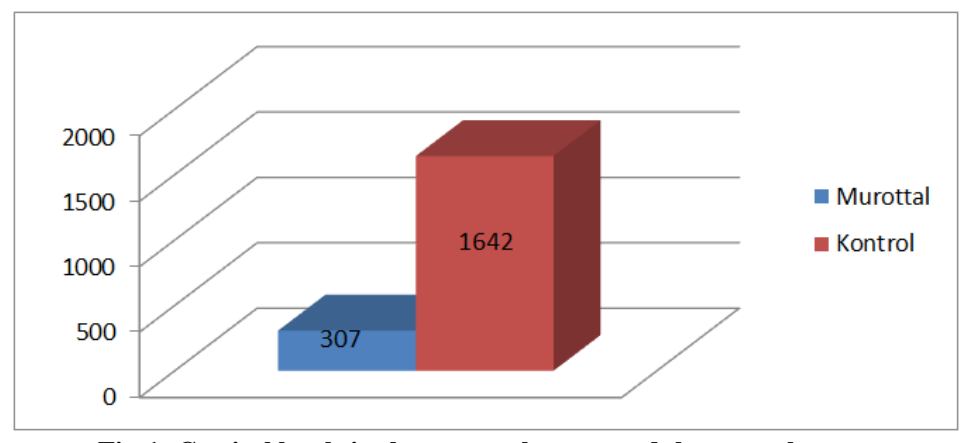

Fig-1: Cortisol levels in the murottal group and the control group

While the difference in delivery time in the murottal group and the control group, the average delivery time in the murottal group was 5.6 hours and the control group was 9.8 hours. Statistical test results using Mann Whitney U obtained $\mathrm{p}=0,000(\mathrm{p}<0.05)$. The relationship of cortisol levels with anxiety levels showed that there was a significant relationship between anxiety levels with cortisol levels in the group given murottal surah ar-rahman namely $(p=0,000, p$ $<0.05)$. Based on the coefficient value $r=0.690$.

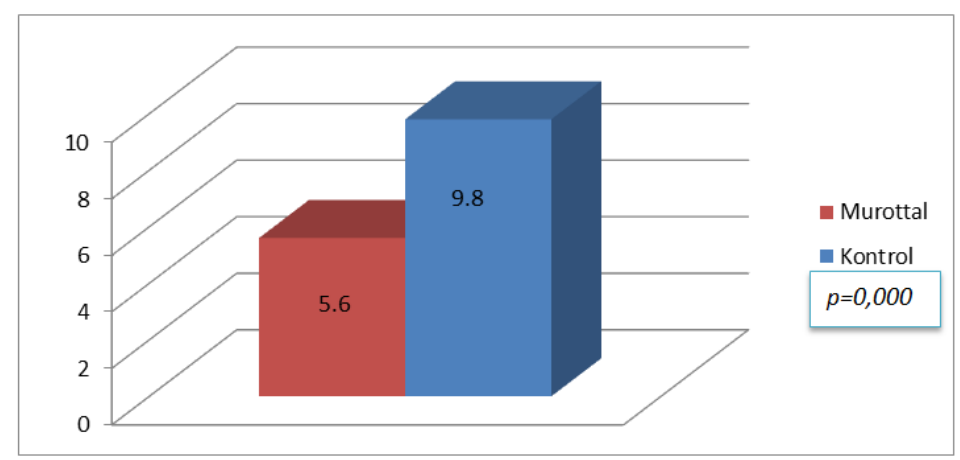

Fig-2: Time of delivery in the murottal group and the control group

\section{DISCUSSION}

In this study shows that there are differences in levels of anxiety, cortisol levels and time of delivery after given murottal surah Ar-Rahman between the intervention group and the control group where the difference in anxiety levels in the two groups is $p=0.001(p<0.05)$, levels cortisol in both groups was $p=0.001(p<\alpha 0.05)$, while delivery time in both groups was $\mathrm{p}=0,000(\mathrm{p}=0.05)$. 
Anxiety before childbirth often experienced by mothers, anxiety experienced by mothers giving birth will increasingly increase; along with the more frequent contractions appear so that this situation will make the mother more uncooperative. Stress in childbirth by reflex causes an increase in maternal ketekolamin levels far above the levels found in women who are not pregnant or pregnant women before delivery.

This is supported by several theories about anxiety, namely labor is not only somative but more psychomatic, namely the existence of psychological elements that affect labor. Every woman who experiences childbirth is always seized with a sense of anxiety and fear, in the process of childbirth the influence of psychic can inhibit labor [6].

In the process of giving birth to a baby, psychological effects can inhibit the birth process or can also accelerate the birth of a baby, the biological function of reproduction is strongly influenced by the psychological life and emotional life of the woman concerned [7].

Childbirth in primiparous cause's anxiety that continues to the onset of tension that can hinder the relaxation of other body parts. It was also explained that anxiety in the face of childbirth is a factor that greatly influences whether or not the labor process, if the mother feels excessive anxiety can cause a decrease in the head of the baby is not appropriate so that the second time will elongate and prolonged labor.

One way to avoid complications caused by anxiety is to use a method that can reduce the increase in the hormone adrenaline in the body of the mother who is a cause of anxiety. The method is distraction. Distraction is a method for relieving anxiety by diverting attention to other things so that patients will forget the anxiety they are experiencing. Pleasant sensory stimuli cause the release of endhorfins which can inhibit anxious stimuli resulting in fewer stimuli being transmitted to the brain.

One of the effective distractions is murottal (listening to the Qur'an), which can reduce stress hormones, activate natural endhorfin hormones, increase feelings of relaxation, and divert attention from fear, anxiety and tension. And improve the body's chemical system so that it can reduce blood pressure and slow down breathing, heart rate, pulse, and brain wave activity. The rate of breathing that is deeper or slower is very good cause calm, emotional control, deeper thinking and better metabolism.

This is caused by maternity mothers who listen to murottal experience calmness and comfort while listening to murottal which has an impact of continued calm after murottal. Asty in Handayani et al. [2] states that murottal is able to stimulate the parasympathetic nervous system which has the opposite effect with the sympathetic nervous system. So that there is a balance in the two autonomic nervous system. This is the basic principle of the emergence of the relaxation response, which is a balance between the sympathetic nervous system and the parasympathetic nervous system. The biggest wish and hope of a mother who will give birth is that labor goes smoothly; she and the baby are healthy. The greatest need is a supporting force, namely the reality of awareness of the existence of Godhead [8].

With murottal therapy, the quality of one's awareness of God will increase, whether that person knows the meaning of the Qur'an or not. This awareness will cause totality surrender to Allah SWT, in this state the brain is in alpha waves, a state of brain energy at a frequency of 7-14 HZ. This can optimally get rid of stress and reduce anxiety [9]. In a calm state the brain can think clearly and can reflect on the existence of God will form coping, or positive expectations in patients [8].

The results of this study are in line with the results of research conducted by Handanyani et al. [2], regarding the effect of Murottal Al-Qur'an therapy for the reduction of labor pain and anxiety in first stage active mothers. With this type of pre-experimental research with one group pretest and posttest design. The sampling technique used was consecutive sampling with a sample of 42 respondents. It shows that there are differences in the average decrease in anxiety levels before and after murottal therapy with a $\mathrm{p}$ value $<\alpha(0,000<0.05)$.

Cortisol levels and anxiety are directly proportional to each other, the more anxious a person is, the higher the cortisol level. Peace and psychological readiness in primiparous mothers will help smoothen the labor process. When mothers experience anxiety and stress, the brain will indirectly work and secrete Corticotropin-releasing hormone (CHR). CHR is a stress hormone master that will trigger the release of glucocorticoid stress hormones. Stimulated by glucocorticoids and other stress hormones, such as adrenaline, the brain and body will experience tension and critical [10, $13,14]$. 


\section{ConClusions AND RECOMMENDATIONS}

There is a change in the level of anxiety in women in the first phase of active phase after administering murottal surah Ar-Rahman. There is a murottal effect of Surah Ar-Rahman on the level of anxiety, cortisol levels and time of delivery in the first stage of labor in the active phase. There is a relationship between anxiety level and cortisol level in the first phase of labor in the active phase. It is recommended for health institutions to make murottal as a reference that can be used in providing non-pharmacological relaxation therapy that is effective and also inexpensive in the delivery of labor which can reduce the level of anxiety and time of delivery.

\section{REFFERENCE}

1. Saifudin. (2009). Ilmu Kebidanan. Jakarta: PT Bina Pustaka.

2. Handayani, R., D.K.K. (2014). Pengaruh Terapi Murottal Al-Qur'an Untuk menurunkan Nyeri Persalinan dan Kecemasan pada Ibu Bersalin Kala I Fase Aktif. Jurnal Ilmiah. Vol 5. No.2, Edisi Desember.

3. Fraser, D.M.M. (2010). Buku Ajar Bidan, EGC

4. Wahida, S. (2015). Terapi Murottal Al-Qur'an Surat Arrahman Meningkatkan Kadar B-Endorphin dan menurunkan Intensitas Nyeri Pada Ibu Bersalin Kala I Fase Aktif. Jurnal Kedokteran Brawijaya, 28(3).

5. Saryono, \& Anggraeni, M.P. (2013). Metodologi Penelitian Kualitatif dan Kuantitatif Dalam Bidang Kesehatan. Nuha Medika: Jakarta.

6. Kartono. (1992). Psikologi wanita, jilid 2,cetakan ke 5 Bandung: Penerbit Maju

7. Dahro, A. (2012). Psikologi Kebidanan: analisis perilaku wanita untuk kesehatan. Jakarta: Salemba Medika

8. Khrisna, A. (2001). Menggapai Langit Biru tak Berbingkai. Jakarta: Puspa Swara.

9. Macgregor, S. (2001). Piece of Mind menggunakan kekuatan pikiran bawah sadar untuk mencapai Tujuan. Jakarta: Gramedia.

10. Aprilia, Y. (2011). Hipnostetri: Rileks, nyaman, dan aman saat hamildan melahirkan. Jakarta: Gagas Medika.

11. Sukma, A. D.K.K. (2013). Pengaruh Musik Klasik (Mozart) terhadap Kemajuan Persalinan Kala I Fase Aktif pada Primigravida (Tesis). Akademi Kebidanan Pamenang.

12. Varney, H. (2007). Buku Ajar Asuhan Kebidanan. Edisi ke Empat, Jakarta: EGC.

13. Cooke, M., Chaboyer, W., \& Hiratos, M.A. (2005). Music and Effect on Anxiety in short waiting periods: a critical Appraisal. Journal of clinical nursing, 145-155

14. Oriordan. (2002). Seni Penyembuhan menggunakan Energi Jiwa. Penerjemah Aristyawati, Bekasi: Gugus Press. 